\title{
ARCHIVES, MusEumS AND \\ COPYRIGHT LAW: RECONCILING THE TRADITIONAL WITH CONTEMPORARY PRACTICES
}

\author{
Susan Corbett*
}

By preserving and providing accessibility to cultural heritage, archives and museums have a crucial role in civil society. "Culture" is not a static concept; ideally, the practices of contemporary archives and museums should adapt to meet the changed expectations and cultural values of society. However, the limited permitted exceptions for archives in the Copyright Act 1994 are an obstacle to archives and museums attaining this goal. For example, the provisions are drafted from a traditional, analogue perspective, albeit with more recent minor changes in an attempt to acknowledge digital technologies. Furthermore, the permitted exceptions are confined to not-for-profit and state archives-a somewhat contentious limit in the 21st century when the Internet promises the means for cultural democracy. Museums are not mentioned at all. In addition, there is no legislative process permitting uses of orphan copyright works. This article explains how the permitted exceptions for archives could be amended in the upcoming review of the Copyright Act to better acknowledge and support cultural heritage institutions. It examines recent amendments in the Copyright, Designs and Patents Act 1988 (UK) and suggests that while some of these amendments would be useful for New Zealand to emulate, additional changes should also be considered.

\section{INTRODUCTION}

Cultural heritage is linked to human dignity and identity. Accessing and enjoying cultural heritage is an important feature of being a member of a community, a citizen and, more widely, a member of society. ${ }^{1}$

* School of Accounting and Commercial Law, Victoria University of Wellington.

1 Farida Shaheed Report of the Special Rapporteur in the field of cultural rights, Farida Shaheed: Copyright policy and the right to science and culture UN Doc A/HRC/28/57 (24 December 2014) at 3. 
By preserving and providing accessibility to cultural heritage, archives and museums (CHIs) play a crucial role in civil society. ${ }^{2}$ Ideally, the practices of contemporary CHIs should be readily adaptable to meet the changed expectations and cultural values of society and to make use of important new technological tools. However, the limited permitted exceptions for archives provided in the Copyright Act $1994^{3}$ and the absence of any practicable provision for orphan copyright works ${ }^{4}$ are obstacles to CHIs attaining their objectives. Without consent from the rights owner of a copyright work, a $\mathrm{CHI}$ is severely limited in the activities it may perform with that work.

Although the significance of CHIs to the collective human memory and identity is broadly accepted, their role within 21 st century civil society is less clear. ${ }^{5}$ In accordance with contemporary archival theory the archivist should not act merely as "a passive guardian of evidence" but instead should demonstrate an "interpretive and narrative role in appraisal". ${ }^{6}$ The traditional model of the archive as being an objective, technical collection of items is thus displaced by a new, less neutral model. ${ }^{7}$ Critical museum theory goes further, arguing for more public participation in museums' collections management. ${ }^{8}$

Content selection is necessary due to the sheer volume of items available to many CHIs today and inevitably the subjective values and rationales of the archivists and curators play a role in the process. ${ }^{9}$ Many governments already acknowledge a limited version of democratisation of culture in pursuing policies of greater accessibility to significant aesthetic works for their citizens. ${ }^{10}$ However, there is less official enthusiasm for encapsulating the potential for the broader democratisation of culture

2 Libraries are often included in the term "cultural heritage institutions"; however, the legal environment for contemporary libraries requires a different analysis. Therefore, libraries are not included in this discussion.

3 Copyright Act 1994, ss 55-56B.

4 The quasi-orphan works provision in the Copyright Act, s 67 provides that copyright is not infringed by acts performed with a work the author of which cannot be ascertained by "reasonable inquiry" provided it is "reasonable to assume" that copyright has expired. This provision does not assist cultural heritage institutions (CHIs) in regard to the many orphan items in their collections in which copyright clearly has not expired.

5 See for example Joan M Schwartz and Terry Cook "Archives, Records, and Power: The Making of Modern Memory" (2002) 2 Archival Science 1; and Andrew Flinn, Mary Stevens and Elizabeth Shepherd "Whose memories, whose archives? Independent community archives, autonomy and the mainstream" (2009) 9 Archival Science 71.

6 Schwartz and Cook, above n 5, at 175.

$7 \quad$ At 176.

8 See for example Lianne McTavish and others "Critical Museum Theory/Museum Studies in Canada: A Conversation" (2017) 46 Acadiensis: Journal of the History of the Atlantic Region 223 at 224.

9 Schwartz and Cook, above n 5, at 175.

10 Kevin V Mulcahy "Cultural Policy: Definitions and Theoretical Approaches" (2006) 35 The Journal of Arts Management, Law, and, Society 319 at 323. 
(described by Kevin V Mulcahy as "cultural democracy") that "provide[s] for a more participatory (or populist) approach" to culture. ${ }^{11}$ Conversely, enabling CHIs to digitise copyright works in their collections could encourage CHIs to accept more items and allow them to provide increased accessibility, thereby responding to criticism that current selection processes do not adhere to calls for the democratisation of culture.

Linked to the process of content selection, the superior status accorded by legislatures to not-forprofit CHIs is contentious. ${ }^{12}$ The permitted exceptions for archives in copyright laws do not apply to collections of cultural artifacts in New Zealand that operate on a for-profit basis. ${ }^{13}$ Such collections may play an important role in preserving significant cultural resources that are not found elsewhere. New Zealand has one of the highest numbers of museums per capita in the world, ${ }^{14}$ yet many collections are able to be viewed only by visitors who are able to travel to their physical premises. This constraint is hardly supportive of cultural democracy.

The permitted exceptions in copyright laws for archives in New Zealand are, similarly to those in many other jurisdictions, unsuitable and impracticable for contemporary practices such as digitisation. Clearly, CHIs should not be required to use outdated technologies to achieve their objectives. Digital technology supports CHIs to undertake efficient and accurate record-keeping, to provide increased public accessibility to their collections and to preserve perfect copies of deteriorating artifacts. ${ }^{15}$ However, the technical requirements of a digital archive are not supported by copyright law. To guard against the loss of digital works caused by commercial obsolescence of programs and platforms, the maintenance of a digital archive requires ongoing copying and migration of the digitally archived works to new platforms. ${ }^{16}$ Copyright law does not allow for this process, generally permitting only one copy to be made for preservation purposes. ${ }^{17}$

The impracticability and limited scope of the archiving exceptions are particularly significant for "born digital" collections. Many early digital works are copyright "orphans"18 and are in imminent

11 At 324. See also Yves Evrard "Democratizing Culture or Cultural Democracy?" (1997) 27 JAMLS 167.

12 Flinn, Stevens and Shepherd, above n 5.

13 See the Copyright Act, s 50 which defines "archive" for the purpose of the permitted exceptions for libraries and archives

14 Conal McCarthy "Museums" Te Ara: The Encyclopedia of New Zealand (22 October 2014) $<$ https://teara.govt.nz>.

15 The National Archives Digital Strategy (March 2017).

16 GM Hodge "An Information Life-Cycle Approach: Best Practices for Digital Archiving" (2000) 5(4) JEP.

17 See for example Copyright Act, s 55; Copyright, Designs and Patents Act 1988 (UK) [CDPA], s 42; and 17 USC $\$ 108$ (which does allow for three replacement copies but is nevertheless similarly impractical for digital preservation purposes).

18 That is, their copyright owners are either not traceable or not identifiable. 
danger of loss; without the ability to make use of copyright exceptions to preserve them, the physical platforms supporting these works will deteriorate and the works could be permanently lost to digital cultural heritage. ${ }^{19}$

New Zealand's Copyright Act is currently under review. It is timely therefore to examine the permitted exceptions for archives in the Copyright Act and consider how they might be amended to ensure they provide a suitable legal environment for contemporary archives and their somewhat neglected sisters, museums. ${ }^{20}$ This article describes and assesses the recent amendments to the permitted exceptions for archives in the Copyright, Designs and Patents Act 1988 (UK) (CDPA) as potentially offering some guidance for the review of the Copyright Act. The article is structured as follows: Part II considers the historical background to the permitted exceptions for archives in copyright laws more generally, noting that the archiving exceptions tend to be similar in both their content and in their unsuitability for purpose in the copyright laws of most common law jurisdictions. Part III focuses on the archiving provisions in the Copyright Act and describes the specific problems for CHIs created by these provisions. In Part IV, recent changes to the permitted exceptions for archives in the CDPA are considered and assessed as a potential model for amendments to the Copyright Act. Part V discusses the implications of the permitted exceptions for archives for Māori culture, while Part VI concludes.

\section{HISTORICAL BACKGROUND TO THE PERMITTED EXCEPTIONS FOR ARCHIVES}

New Zealand archivists appear to have had little interest in copyright matters until the 1980s when the reform of the Copyright Act 1962 came under discussion. ${ }^{21}$ The Copyright Act 1962 contained just one provision specific to archives. ${ }^{22}$ Section 61 of that Act provided that copyright in "any work or other subject matter ... comprised in any public records or public archives under the charge of the Chief Archivist ... and ... available for public reference" would not be infringed by the provision of

19 See United Nations Educational Scientific and Cultural Organization UNESCO Charter on the Preservation of the Digital Heritage UN Doc IFAP-2003/COUNCIL.II/4 (March 2003); and United Nations Educational Scientific and Cultural Organization "Memory of the World" <https://en.unesco.org>. See also Susan Corbett "Digital Heritage: Legal Barriers to Conserving New Zealand's Early Video Games" (2007) 13 NZBLQ 47; and Julia Mary Thompson "Have we dropped a stitch? Collecting born digital documentary heritage in New Zealand cultural heritage institutions" (MLIS Thesis, Victoria University of Wellington, 2010).

20 The word "museum" does not appear in the Copyright Act. The archiving exceptions apply to museums' collections only insofar as they comply with the definition of a collection of documents (as defined in s 2 of the Official Information Act 1982), or they include a holding of public archives in the capacity of "an approved repository" as defined in the Public Records Act 2005: see Copyright Act, s 50(1)(a)(vi) and 50(1)(b).

21 For instance, despite the Copyright Act 1913 containing no reference to archives, there is no record of any submissions made by archivists to the committee (the Dalglish Committee) tasked with reviewing that Act: Report of the Copyright Committee 1959 (Government Printer, H46, 1959).

22 Section 61. 
a copy to "any person". The New Zealand Film Archive submitted to the review of the 1962 Act that it should be permitted to make copies of films for restoration or preservation. ${ }^{23}$ This proposal was opposed by the Director of National Archives, who argued that the National Archives and the National Library had statutory obligations to preserve films, whereas "the New Zealand Film Archive does not have sole responsibility in the film area, indeed it has no 'official role' at all". ${ }^{24}$ Apart from this exchange (which reflects the traditional opinion that the state should manage all cultural matters for its citizens) there is no report of any submissions made by archivists to the review of the Copyright Act 1962 which eventually led to the Copyright Act 1994.

New Zealand followed the examples provided in the CDPA when drafting the permitted exceptions for archives in the Copyright Act 1994. However, permitted exceptions for libraries and archives had first appeared in the Copyright Act 1956 (UK) seemingly without much debate or discussion. ${ }^{25}$ Strangely, although s 7 of that Act is headed "[s]pecial exceptions as respects libraries and archives" the contents of $\mathrm{s} 7$ does not contain any mention of archives or archivists, referring only to libraries and librarians. ${ }^{26}$ The CDPA, however, includes two permitted exceptions for archives. ${ }^{27}$ Similarly to its predecessor, it is difficult to locate any evidence of archivists providing input into the CDPA. ${ }^{28}$ The report of the committee appointed in 1974 to consider whether changes to United Kingdom copyright and design law were desirable (the Whitford Report) does, however, include discussion of the library and archives provision in United States' copyright law. ${ }^{29}$ It seems possible that the United States provision provided some influence on the equivalent provisions in the CDPA (since the recommendation in the Whitford Report, that a blanket licensing scheme be provided for

23 Law Reform Division Department of Justice The Copyright Act 1962 Options for Reform (1989) at [4.31].

24 At [4.31].

25 Copyright Act 1956 (UK), s 7. The list of organisations providing written submissions to the Report of the Copyright Committee (Cmd 8662, 1951) [Gregory Report] includes: The Association of Special Libraries and Information Bureaux, the Historical Manuscripts Commission and the Society of Authors. However, there is no discussion of the input from these organisations within the body of the Report.

26 The one exception is that the Copyright Act 1956 (UK), s 7(6)(c) refers to a "manuscript or a copy of the work kept in a library, museum or other institution" (emphasis added).

27 CDPA, ss 40A and 43 .

28 The list of organisations providing written submissions to the Department of Trade Copyright and Designs Law: Report of the Committee to Consider the Law on Copyright and Designs (Cmd 6732, 1977) [Whitford Report] includes the Historical Manuscripts Commission and the Society of Authors. However, there is no discussion of the input from these organisations within the body of the Report.

29 Whitford Report, above $\mathrm{n} 28$, at 61, reiterating the contents of s 108 of the Copyright Law Revision Bill 1976 (now 17 USC $\S 108$ ). 
all reprographic reproductions of copyright works, including by libraries, ${ }^{30}$ was not taken up by the legislature when drafting the CDPA).

The history of the permitted exceptions for libraries and archives in United States' copyright law is extensively documented. ${ }^{31}$ It began with the development of the micro-copier which, while of concern to copyright owners because it made copyright infringement readily available, nevertheless would clearly be an invaluable resource for scholars throughout the country. The widespread availability of the micro-copier encouraged publishers in the United States to enter into the voluntary Gentlemen's Agreement of 1935 with librarians, ostensibly in order to assist researchers, but more likely to protect their own business models by placing acceptable limits on the potential use of the micro-copier. ${ }^{32}$ The Gentlemen's Agreement is believed to be the foundation for the exceptions for libraries and archives in the Copyright Act 1976 (US), ${ }^{33}$ providing guidelines for the amount of copying that could be carried out by CHIs on behalf of researchers and allowing librarians and archivists to preserve their collections. ${ }^{34}$ Peter Hirtle has commented on the process as follows: ${ }^{35}$

In the 1976 Copyright Act, the limited vision of acceptable behavior by librarians acting on behalf of researchers, became codified in law in Section 108. In very real ways, researchers, librarians, archivists, and museum specialists still live with the consequences of the process that led to the development of the Gentlemen's Agreement.

The Joint Committee on Materials for Research, whose deliberations led to the Gentlemen's Agreement, had focused its discussions on five main areas ${ }^{36}$ generally targeted at the needs of researchers but ignoring other reasons for reproducing library and archival materials, such as for preservation, deposit in another library or archive, or educational use. ${ }^{37}$ Although the resulting Gentlemen's Agreement was intended to encourage legal codification of activities that were already common practice in the field of research institutes, libraries, museums and archives, it was not successful in regard to most of the areas discussed by the Joint Committee. ${ }^{38}$ Instead, the legislature

30 Whitford Report, above n 28, at 74.

3117 USC $\$ 108$.

32 Peter B Hirtle "Research, Libraries, and Fair Use: The Gentlemen's Agreement of 1935" (2006) 53 J Copyright Soc'y USA 545 at 548.

3317 USC \& 108.

34 Hirtle, above n 32, at 546, citing Kenneth Crews Copyright, Fair Use, and the Challenge for Universities: Promoting the Progress of Higher Education (University of Chicago Press, Chicago, 1993) at 30-31.

35 At 549.

36 At 548-549.

37 At 554-557.

38 At 554-557. 
introduced a restrictive policy that permitted research institutes, libraries, museums and archives to use copyright works in very limited contexts. ${ }^{39}$ Since the other reasons for reproducing library and archival materials were not covered in the Gentlemen's Agreement, the legislature also ignored them: ${ }^{40}$

Nor did the legislation do more for libraries, archives, and museums than protect their personnel. It did

not provide for any of the other copying a library, archives, or museum might wish to undertake, including

for the preservation of their collections or to share rare and unique items with other institutions.

In 1938 the Joint Committee sought to revise the Gentlemen's Agreement by including a provision that personal copying of copyright works by scholars should be permitted, that libraries and archives should not be held responsible for the copying they do on behalf of individuals and that copying of out of print books should be permitted (possibly subject to a statutory licence). ${ }^{41}$ The resulting exceptions for libraries and archives in the United States Copyright Act (which has been amended since 1976, albeit to a limited extent) ${ }^{42}$ are similar to those in the CDPA (prior to its recent amendments) ${ }^{43}$ and the Copyright Act, and are similarly inadequate for CHIs to achieve their objectives in the 21 st century. ${ }^{44}$ Indeed, although United States archives and libraries are explicitly permitted to claim the defence of fair use, ${ }^{45}$ it seems that there is a reluctance to rely on this defence since there is uncertainty regarding how, in practice, this ability would be interpreted by the courts. ${ }^{46}$

The unsuitable provisions in copyright laws for CHIs can also be traced back to a plethora of submissions from publishers and other copyright owners to the early reports and discussion papers on copyright law in most countries, alongside a dearth of submissions from copyright users, including archivists and other cultural institutional employees. It is trite that copyright policies have always

39 At 549.

40 At 567. See also at 548-549.

4117 USC $\$ 108$

42 See 17 USC $\S 108(\mathrm{~h})$ which permits libraries, archives and non-profit educational institutions to carry out many activities with a published work that would otherwise be an infringement of copyright during the final 20 years of the work's term of copyright protection (unless the work is subject to normal commercially exploitation and a copy or phonorecord of the work can be obtained at a normal commercial price). The exception does not apply to musical, pictorial, graphic or sculptural works, films or other audio-visual works (apart from audio-visual news works).

43 The 2014 amendments to the CDPA that provide permitted exceptions for libraries and archives that extend well beyond those provided in 17 USC $\$ 108$ are discussed below.

44 For analysis and criticism of 17 USC $\$ 108$, see Laura Gasaway "Archiving and preservation in US copyright law" in Estelle Derclaye (ed) Copyright and Cultural Heritage: Preservation and Access to Works in a Digital World (Edward Elgar, Cheltenham (UK), 2010) 131.

4517 USC $\S 108(f)(4)$.

46 Gasaway, above n 44, at 150-151. 
represented a balance (which is not always achieved) between the claims of publishers and authors and the public interest; as Francis Skone-James comments, "the creator ... wants the maximum commercial exploitation of his creation, on the one hand, and the public ... wants unfettered use of the creation, on the other". ${ }^{47}$

In addition, when introducing exceptions to copyright law, legislatures have been constrained by the requirement to adhere to a rule known as "the three-step test" in international agreements. ${ }^{48}$ The three-step test requires that states: ${ }^{49}$

... confine limitations or exceptions to exclusive rights to certain special cases which do not conflict with

a normal exploitation of the work and do not unreasonably prejudice the legitimate interests of the rights

holder.

The three-step test has been described as the rule that "most directly constrains the ability of policy makers ... in designing new exceptions and limitations". ${ }^{50}$ Contemporary scholars are, however, somewhat ambivalent on the correct interpretation of the test. Some argue that the traditional interpretation and resulting implementation of the three-step test into domestic law (albeit the interpretation approved of by the World Trade Organization $)^{51}$ is too cautious and urge that a broader, less literal view of the test should now be taken. ${ }^{52}$ Others argue that the traditional interpretation is more consistent with the interpretation requirements of the Vienna Convention on the Law of

47 FE Skone James "The United Kingdom Copyright Act of 1956" [1957] Bulletin of the Copyright Society of the USA 117 at 118. See also the Whitford Report, above n 28, at 66, commenting that "[p]ublishers, not surprisingly, took a different line from libraries".

48 See the Berne Convention for the Protection of Literary and Artistic Works (as amended) 1161 UNTS 3 (opened for signature 24 July 1971, entered into force 15 December 1972) [Berne Convention]; the Marrakesh Agreement Establishing the World Trade Organization 1867 UNTS 3 (opened for signature 15 April 1994, entered into force 1 January 1995), annex 1C (Agreement on Trade-Related Aspects of Intellectual Property Rights) [TRIPS Agreement]; the World Intellectual Property Organisation Copyright Treaty 2186 UNTS 121 (opened for signature 20 December 1996, entered into force 6 March 2002) [WCT]; and the World Intellectual Property Organisation Performances and Phonograms Treaty 36 ILM 76 (adopted 20 December 1996, entered into force 20 May 2002) [WPPT].

49 TRIPS Agreement, above $\mathrm{n} 48$, art 13, which mainly reiterates art 9 of the Berne Convention, above $\mathrm{n} 48$ (although the latter applies only to the right of reproduction). See also the WCT, art 10; and the WPPT, art 16 , both above $n 48$.

50 Daniel J Gervais (Re)structuring Copyright: A Comprehensive Path to International Copyright Reform (Edward Elgar Publishing, Cheltenham (UK), 2017) at 59.

51 See United States - Section 110(5) of the US Copyright Act WT/DS160/R, 15 June 2000.

52 Patrick R Goold "The Interpretive Argument for a Balanced Three-Step Test?" (2017) 33(1) Am U Int'l L Rev 187 at 189. 
Treaties, ${ }^{53}$ even suggesting that, on a strictly literal application of the three-step test, the United States' open-ended "fair use" provision is not compliant. ${ }^{54}$ The divisiveness of the academy on the issue suggests that policy makers and legislators may hesitate before taking a more flexible approach when interpreting the three-step test in relation to introducing or amending exceptions and limitations in national copyright legislation. 55

Although it is speculation (since there is no record), it seems possible that the copyright law of the United Kingdom, as applied to archives and libraries in the CDPA, may have followed the United States' example to a certain extent. ${ }^{56}$ New Zealand, in turn, closely followed the CDPA in providing limited exceptions in the Copyright Act for archivists. ${ }^{57}$

\section{THE PERMITTED EXCEPTIONS IN NEW ZEALAND LAW FOR CHIS}

The permitted exceptions for archives in the Copyright Act are restricted to state-funded bodies such as Archives New Zealand (Te Rua Mahara o te Kāwanatanga), the National Library, sound and film archives operated by state-funded media bodies, and certain not-for-profit bodies maintaining archival collections of "documents". ${ }^{58}$ The exceptions do not explicitly include museums, although they are stated to apply to "documents" of "historical significance" or "public interest" in the custody of a not-for-profit body (which could include museums), ${ }^{59}$ and to "an approved repository" holding

53 Vienna Convention on the Law of Treaties 1155 UNTS 331 (opened for signature 23 May 1969, entered into force 27 January 1980) art 31, which requires parties to interpret provisions "in accordance with the ordinary meaning".

54 See discussion in Goold, above n 52, at 230. See also Ruth Okediji "Towards an International Fair Use Doctrine" (2000) 39 Colum J Transnat'l L 75 at 115 and 126-128.

55 See for example Gervais, above n 50, at 87-91.

56 See discussion in Part II.

57 For analysis of the permitted exceptions for archives in the Copyright Act 1994, see Susan Corbett "Copyright Norms and Flexibilities and the Digitisation Practices of New Zealand Museums" (2013) 29(1) LIC 55.

58 Copyright Act, s 50. The relevant provisions are ss 50, 55, 56, 56A, 56B and 56C. Sections 57 and 57 A apply only to Radio New Zealand Ltd, Television New Zealand Ltd and the New Zealand Film Archive Inc and are not included in the analysis in this article.

59 Copyright Act, s 50(1). For the definition of "document" see the Official Information Act, s 2. 
public archives as defined in the Public Records Act $2005 .{ }^{60}$ A museum employee aptly summed up the problems for the non-lawyer: ${ }^{61}$

... they are useless ... if a museum person reads the Act, you don't see the word "museum" there, not even in the definitions. Consequently it is very difficult, because as soon as you are including people who are not trained lawyers and do not know the parliamentary process and all the documentation that lead up to the change of the Act, they are immediately put off, and are, like, "well we are obviously not in there and so it doesn't apply to museums".

The restriction of the archiving exceptions to certain other not-for-profit institutions adds further uncertainty. The requirements for a CHI to qualify as a not-for-profit institution are unclear. ${ }^{62}$ This problem is not confined to New Zealand CHIs. For example, in their 2005 guidelines for Australian CHIs seeking to digitise their collections, Emily Hudson and Andrew Kenyon asserted that: ${ }^{63}$

There is a strong argument that the mere existence of commercial activities within an institution (such as a gift shop or research service) would not, of itself, mean the collection is maintained for the purpose of deriving a profit.

Should a CHI make digitised images of its collections available online for public access and purchase however, such activity might be found to override the not-for-profit status of the institution. Moreover, if not-for-profit in the context of a CHI is understood as being a synonym for "state funded" (since clearly it will be mainly state-funded institutions that can run under a not-for-profit paradigm) then it is contentious. As discussed earlier in the article, the role of the state in culture is under review contemporary scholarly writing tends to argue that cultural policies should encourage cultural democracy. ${ }^{64}$

There are three potential categories of copyright items held by a CHI: items whose copyright has been assigned to the institution; items whose copyright owner is known and traceable; and items which

60 See Public Records Act, ss 4 and 26. The process of identifying any such "approved repositories" has proved elusive.

61 Anonymous quote cited in Susan Corbett Archiving our Culture in a Digital Environment: Copyright law and Digitisation Practices in Cultural Heritage Institutions (The New Zealand Law Foundation, November 2011) at 22 .

62 Stefan Toepler and Volker Kirchberg Museums, Merchandising, and Nonprofit Commercialization (Working Paper, January 2002); and Sotheby's Institute of Art "The Business Model of the Nonprofit Museum" (10 January 2018) <www.sothebysinstitute.com>.

63 Emily Hudson and Andrew T Kenyon "Copyright and Cultural Institutions: Guidelines for Digitisation" (University of Melbourne Law, Centre for Media and Communications Law, Legal Studies Research Paper No 140, August 2005) at [6.2].

64 Mulcahy, above n 10; Evrard, above n 11; and Jack M Balkin "Digital Speech and Democratic Culture: A Theory of Freedom of Expression for the Information Society" (2004) 79 NYU L Rev 1. 
are orphan works (that is, although they are protected by copyright their copyright owner is either not known or is untraceable). ${ }^{65}$ The moral rights of an author or creator potentially add further complexity, but are not addressed within the permitted exceptions. The moral right to be identified as the author of a literary, dramatic, musical, or artistic work, or the director of a film, applies (inter alia) whenever a work is communicated to the public or exhibited in public. ${ }^{66}$ Clearly this provision applies to CHIs, but is unlikely to be problematic since the right to be identified applies only if it has been asserted. ${ }^{67}$ The $\mathrm{CHI}$ will be alerted to the fact that the author or director has asserted their moral right to be identified by one of the following ways: a statement in an assignment of copyright in the work; a separate written and signed instrument; by noting that the author is identified on the work or an authorised copy released for public exhibition; on a frame or mount to which the work or copy is attached; or in a licence granted by the copyright owner permitting copies to be made for public exhibition. ${ }^{68}$

The moral right to object to derogatory treatment of the work is more problematic for CHIs. The practice of digitisation of a photograph or art work and displaying it as a thumbnail image, for example, might be found to infringe not only the copyright in the work, ${ }^{69}$ but also an artist's or photographer's moral right not to have their work subjected to derogatory treatment. ${ }^{70}$ This is particularly true of the creators of digital media works, in relation to which the integrity of the "audience experience" is seen as a crucial element of the work itself. An alteration to the digital platform on which the work is displayed may be considered by the artist to have an adverse effect upon audience experience. ${ }^{71}$ For example, in a recent Canadian case, a photographer argued that the scanning of his work "necessarily" resulted in lower resolution copies that were inferior to authorised

65 This section is adapted from Susan Corbett and Mark Boddington Copyright Law and the Digitisation of Cultural Heritage (Centre for Accounting, Governance and Taxation Research, WP No 77, 2011).

66 Copyright Act, s 94.

67 Copyright Act, s 96(1).

68 Copyright Act, s 96(2)-(3).

69 The well-known rulings in Bridgeman Art Library Ltd. v Corel Corp 25 F Supp 2d 421 (SD NY 1998) at 423424 and Bridgeman Art Library Ltd v Corel Corp 36 F Supp 2d 191 (SD NY 1999) which found there was no copyright in photographs of public domain artworks have been widely criticised and are largely ignored by CHIs which tend to claim that copyright exist in their digital versions of public domain artistic works. See for example Caitlin A Buxton "Bridgeman Art Library, Ltd. v Corel Corporation Revisited: Authors Guild v Hathitrust and the New Frontier of Fair Use" (2015) 11 Okla JL \& Tech 77.

70 Copyright Act, s 98.

71 On the difficulty of protecting moral rights in their current form in a digital environment see Mira Sundara Rajan "Moral Rights in the Digital Age: New Possibilities for the Democratisation of Culture" (paper presented to 16th BILETA Annual Conference, University of Edinburgh, Scotland, 9-10 April 2001) at 3. 
prints and that the availability of these inferior copies in the marketplace threatened the integrity of his work and was damaging to his reputation. ${ }^{72}$

Moral rights may not be assigned, but may be waived, in New Zealand copyright law. ${ }^{73}$ The law permits a waiver to be limited to a specific moral right such as the moral right to object to derogatory treatment of work; a waiver is not necessarily required to apply to all the moral rights pertaining to that author. ${ }^{74}$ Ideally, therefore, a CHI should obtain not only an assignment of copyright, but also a waiver of the moral right to object to derogatory treatment of the work from its author. This may be difficult, if not impossible, since the copyright owner is not necessarily the author, artist, or photographer. Moreover, even supposing the author is traceable, he or she may be reluctant to waive his or her moral right to object to derogatory treatment of his or her work.

The increasing awareness of the significance of copyright law to their activities (such as the digitisation of collection items for collections management, preservation and online display) has led some CHIs to require, as a matter of good practice, that in order for any item to be accepted into the collection, it must be accompanied by an assignment of its copyright to the institution. This requirement is, however, generally not strictly imposed, either because many donors do not know whether or not they are the copyright owners or because the whereabouts of the copyright owner is unknown. ${ }^{75}$

Several CHIs provide a vague and somewhat ambiguous reference to copyright ownership in their collection advice for prospective donors. For instance, Auckland Museum's online information about donating states: "[f]or objects in which copyright exists, copyright licensing will be discussed as part of the donation process, in accordance with the New Zealand Copyright Act 1994". ${ }^{76}$ Otago Museum requires that "[f]ull title must accompany any item to be accessioned into the collections". ${ }^{77}$ Other items may have been donated to the institution without an assignment of copyright, but with full and accurate details of the copyright owner. For these items the institution can contact the copyright owner for permission to carry out activities which would otherwise be an infringement of copyright, such as

72 Andrew Collett v Northland Art Company Ltd and Bremner Fine Art Inc 2018 FC 269 at [35]. Somewhat controversially, Justice Gleeson declined to consider the argument that Collett's moral right not to have his work subject to derogatory treatment had been infringed, on the grounds that he had already ruled that there had been an infringement of moral rights in that the plaintiff's moral right of attribution had been infringed, at [41]. Critics have noted that there is no restriction in Canadian copyright legislation against the award of separate remedies for concurrent infringement of two or more moral rights.

73 Copyright Act, s 107.

74 Copyright Act, s 107(3)(b).

75 Corbett Archiving our Culture in a Digital Environment: Copyright law and Digitisation Practices in Cultural Heritage Institutions, above n 61, at 24.

76 Auckland Museum "Donating objects to our Collections" <www.aucklandmuseum.com>.

77 Otago Museum Collections and Research Collection Policy 2015-2020 at [7.0]. 
digitisation of the item. If consent is not obtained, the institution is unlikely to proceed, ${ }^{78}$ unless they are prepared to adopt a risk management process. ${ }^{79}$

Given the unsatisfactory state of the law, some CHIs adopt a risk management strategy. ${ }^{80}$ Risk management requires the potential ramifications of unauthorised digitisation activities for the institution to be assessed, usually by considering the likelihood of an aggrieved copyright owner pursuing a legal action, rather than any consideration of actual liability. For example, when digitisation is undertaken for collection management purposes, such as in-house cataloguing, access to the digital copies is limited to the staff of the institution and it is presumed, probably correctly, that copyright owners are likely to remain unaware that their rights have been breached. ${ }^{81}$ Potentially more problematic for a $\mathrm{CHI}$ is the practice of making the institution's digitised collection available online for the purpose of enhancing public access. Under a risk management strategy a CHI might publish images of copyright items on its website as a means to enhance public access to the collection and also to expand the institution's own knowledge of its collections. ${ }^{82}$ The online display of images by CHIs is sometimes justified as being the only way to achieve this, particularly for orphan copyright works. It is presumed that at least some of the unknown copyright owners will make themselves known, thus, creating the potential for a relationship that is mutually beneficial. If a copyright owner objects to the display of an image of his or her original work the institution will usually apply a takedown policy according to which it will, on request from a copyright owner, remove the image of that work from its website. Such an approach is legally precarious. The relevant permitted exception is explicit: it provides that an archive may communicate one lawfully obtained digital copy in protected format to an authenticated user. ${ }^{83} \mathrm{CHIs}$ rely on their not-for-profit "public good" status and the institution's takedown policy as insurance, speculating that these features are likely to protect the institutions from potential legal action. ${ }^{84}$

78 Paul Klimpel "Copyright confusion puts Europe's cultural heritage at risk" (6 July 2015) iRIGHTS info $<$ https://irights.info>.

79 Risk management is recommended by some CHI professionals, but nevertheless remains contrary to law: see for example Naomi Korn Museums, Orphan Works and Risk Management (2015); and Jisc "Orphan Works and Risk Management" <https://sca.jiscinvolve.org>.

80 Lorna M Hughes Digitizing Collections: strategic issues for the information manager (Facet Publishing, London, 2004); and Klimpel, above n 78.

81 See Ministry of Business, Innovation and Employment Exceptions for the 'GLAM' sector: "(institutions are) forced to 'break the law' - (as there is) uncertainty about copying for collection management purposes".

82 See for example the Museum of New Zealand Te Papa Tongarewa "About Collections Online" <www.tepapa.govt.nz/discover-collections>.

83 Copyright Act, s 56A.

84 See (in relation to potential legal liability of museums more generally) Janet Ulph "Frozen in Time: Orphans and Uncollected Objects in Museum Collections" (2017) 24 IJCP 3. 
Alternatively, some CHIs adopt a risk averse approach, choosing not to digitise or publish any copyright work online without the consent of the copyright owner. Although legally secure, such an approach leads to a selective representation of items online that frequently defies any rational selection policy from a cultural perspective. The overarching objectives of a $\mathrm{CHI}$ (and the prioritisations demanded by these objectives) are thereby set aside in favour of an alternative framework that is dictated solely by copyright considerations. Under this framework, decisions are made based on what may be legally digitised, rather than what would be of heritage value for the public interest in research, education and culture.

\section{CHANGES TO THE COPYRIGHT, DESIGNS AND PATENTS ACT 1988 (UK) (CDPA): AN EXEMPLAR FOR THE REVIEW OF THE COPYRIGHT ACT 1994?}

In 2014 the CDPA was significantly amended by the Copyright and Rights in Performances (Research, Education, Libraries and Archives) Regulations 2014 (UK). Alexander Herman describes the Regulations as "an annus mirabilis for copyright law in the United Kingdom" concluding that in reality "the law has now caught up with common practice". ${ }^{85}$ Peter Wienand, however, warns that: ${ }^{86}$

Although generally welcome, these new Regulations arguably represent a missed opportunity to move away from - or at least clarify - the murky definitions of "fair dealing" in the UK copyright regime.

Indeed, the term is if anything wider and more subjective than before.

The Regulations included changes to the permitted exceptions for libraries and archives. As discussed above, the permitted exceptions for archives in the Copyright Act are very similar to those provided in the copyright laws of other common law jurisdictions and were largely based on the provisions in the CDPA. It is instructive, therefore, to examine the revised permitted exceptions for archives in the CDPA, to assess whether a similar approach should be taken in the review of the Copyright Act.

\begin{tabular}{|l|l|}
\hline \multicolumn{1}{|c|}{ CDPA Amendments } & \multicolumn{1}{|c|}{ Recommendations for the Copyright Act } \\
\hline $\begin{array}{l}\text { Some of the permitted exceptions for archives } \\
\text { and libraries in the CDPA now explicitly } \\
\text { include museums, with "museum" defined to } \\
\text { include a "gallery". } 87\end{array}$ & $\begin{array}{l}\text { Museums must be explicitly included as being } \\
\text { eligible to make use of the permitted exceptions } \\
\text { for libraries and archives. As Gasaway } \\
\text { explains, "[m]useums perform public functions } \\
\text { that are similar to libraries and archives. ... } \\
\text { Further, museums have the same need to }\end{array}$ \\
\hline
\end{tabular}

85 Alexander Herman "The Year of Living Exceptionally: New Copyright Exceptions in UK Law" (2014) 19 Art Antiquity and Law 303 at 303 and 313.

86 Peter Wienand "UK Copyright infringement exceptions - how the changes will affect you" (14 July 2018) $<$ https://dokumen.tips/category/documents>.

87 See CDPA, ss 40B, 42, 43A, 44B and sch ZA1. 


\begin{tabular}{|c|c|}
\hline & $\begin{array}{l}\text { reproduce and distribute copies of works to } \\
\text { researchers and scholars". }{ }^{88} \text { Similarly to the } \\
\text { CDPA, }{ }^{89} \text { "museums" should be defined to } \\
\text { include "galleries". }\end{array}$ \\
\hline $\begin{array}{l}\text { Any not-for-profit archive may now lend copies } \\
\text { of a copyright work }{ }^{90} \text { (formerly this exception } \\
\text { applied only to a "prescribed archive"). }{ }^{91}\end{array}$ & $\begin{array}{l}\text { There is no equivalent provision in the } \\
\text { Copyright Act. }\end{array}$ \\
\hline $\begin{array}{l}\text { A library, archive, museum or educational } \\
\text { establishment may communicate a lawfully } \\
\text { acquired work (not specifically limited to } \\
\text { digital works) to the public or make the work } \\
\text { available to the public by means of a dedicated } \\
\text { terminal on its premises for the purposes of } \\
\text { research or private study. } 92 \text { The text and } \\
\text { grammatical structure of this provision implies } \\
\text { that "communicating" is not required to be via } \\
\text { a dedicated terminal - presumably allowing } \\
\text { communication by email. Notably, however, } \\
\text { this interpretation would diverge from the } \\
\text { European Directive on the harmonisation of } \\
\text { copyright and related rights in the information } \\
\text { society, which the Regulations were intended to }\end{array}$ & $\begin{array}{l}\text { The Copyright Act confines the permitted } \\
\text { exception for an archive to "communicate" to } \\
\text { the communication of digital copies of works. }{ }^{97} \\
\text { A communicated work must be unalterable - } \\
\text { presumably by the application of a } \\
\text { technological protection measure (TPM). }{ }^{98} \\
\text { Given the requirement for a TPM, the } \\
\text { additional requirement that communication } \\
\text { must be limited to "authenticated users" } 99 \text { is } \\
\text { unnecessary and should be replaced by "the } \\
\text { public"). This provision is ambiguous: it also } \\
\text { requires that the archivist has obtained the } \\
\text { digital copy "lawfully". It is not clear whether } \\
\text { this includes a digital copy of an analogue work } \\
\text { that was made by an archivist under s } 55 \text { or a } \\
\text { digital copy of an unpublished work made } \\
\text { under s } 56 \text {. }\end{array}$ \\
\hline
\end{tabular}

88 Gasaway, above n 44, at 141 .

89 CDPA, s 43A

90 "'Conducted for profit' in relation to a library, archive or museum means a body of that kind which is established or conducted for profit or which forms part of, or is administered by a body established or conducted for profit": CDPA, s 43A(4).

91 Copyright and Rights in Performances (Research, Education, Libraries and Archives) Regulations 2014 (UK), sch, cl 3, amending CDPA, s 40A(2)(3).

92 CDPA, s 40B.

97 Copyright Act, s 56A.

98 Copyright Act, s 56A(c).

99 Copyright Act, s 56A. 


\begin{tabular}{|c|c|}
\hline $\begin{array}{l}\text { There is no definition of a "dedicated terminal" } \\
\text { provided in the CDPA. Although Herman } \\
\text { speculates that perhaps a dedicated terminal } \\
\text { might include "movable consoles that visitors } \\
\text { hire and take with them", }{ }^{94} \text { it is likely that } \\
\text { rulings from the Court of Justice of the } \\
\text { European Union (CJEU) will (at least in the } \\
\text { short term) provide guidance on the } \\
\text { interpretation of a dedicated terminal for the } \\
\text { United Kingdom courts. For example, in } \\
\text { Technische Universität Darmstadt v Eugen } \\
\text { Ulmer KG the CJEU stated: }{ }^{95} \\
\text { Article } 5(3) \text { (n) of Directive } 2001 / 29 \text { must be } \\
\text { interpreted to mean that it does not extend to } \\
\text { acts such as the printing out of works on } \\
\text { paper or their storage on a USB stick, carried } \\
\text { out by users from dedicated terminals ... } \\
\text { In any event, the provision will allow } \\
\text { institutions to make available to the public } \\
\text { much more of their collections than had hitherto } \\
\text { been possible due to physical space constraints. }\end{array}$ & $\begin{array}{l}\text { Archives should also be permitted to make } \\
\text { works available to the public via terminals on } \\
\text { their premises. } \\
\text { Perhaps surprisingly, there is no reference to } \\
\text { any contractual override applying to this } \\
\text { provision, implying that it will be (once } \\
\text { amended) of important significance and } \\
\text { practical benefit to the New Zealand public. } \\
\text { Although the omission of a contractual override } \\
\text { clause may discourage copyright owners from } \\
\text { depositing their works into CHI collections, } \\
\text { there is no apparent reason why a CHI could not } \\
\text { purchase a copy for its collection. }\end{array}$ \\
\hline
\end{tabular}

93 Directive 2001/29 on the harmonisation of certain aspects of copyright and related rights in the information society [2001] OJ L167/10.

94 Herman, above $\mathrm{n} 85$, at 311.

95 Case C-117/13 Technische Universität Darmstadt v Eugen Ulmer KG ECLI:EU:C:2014:2196 at [57] (emphasis added). 
Similarly to article 5(3)(n) of the European Directive, the CDPA specifically allows for a contractual override of this provision. ${ }^{96}$ Thus, it is difficult to conceive of how useful in practice this provision will be.

Copying of items (meaning a work or a copy of a work) in the permanent collections of not-forprofit libraries, archives or museums for preservation or replacement or to provide a copy to another such institution is permitted. ${ }^{100}$ The original item must not be accessible to the public, but must be retained for reference purposes or for loan to another such institution. ${ }^{101}$ This provision is not able to be overridden by contract. ${ }^{102}$

This provision is important because it does not require (as the previous provision had required) that the original item be damaged or destroyed before a copy is made. Thus, allowing for copies that anticipate, for example, that a digital platform on which an item is supported or displayed may become obsolete. ${ }^{103}$

A new provision confirming the permitted uses of orphan works by a "relevant body" has been inserted into the CDPA. ${ }^{107} \mathrm{~A}$ relevant body
The Copyright Act permits archivists to make a single copy of a copyrighted work in the archive for preservation and replacement, provided it is not reasonably practicable to purchase a copy of the item in question. ${ }^{104}$ A digital copy may only be made where required for replacement of a lost, damaged or destroyed item. ${ }^{105}$ If a digital copy is made, the original item must be removed from public access, apart from for specific research purposes. ${ }^{106}$

The Copyright Act should be amended in the same way as the equivalent provision in the CDPA has been amended, to allow for copying in anticipation of future technological problems.

The Copyright Act urgently needs to provide a process for orphan copyright works. Not doing so risks the likelihood that businesses and CHIs

96 CDPA, s 40B(3)(c): the work or copy of a work may only be "communicated or made available in compliance with any purchase or licensing terms to which the work is subject".

100 See the CDPA, s 42.

101 CDPA, s 42(2).

102 CDPA, s 42(7).

103 Intellectual Property Office Exceptions to copyright: Libraries, archives and museums (October 2014).

104 Copyright Act, s 55.

105 Copyright Act, s 55(4).

106 Copyright Act, s 55.

107 CDPA, s 44B. 


\begin{tabular}{|c|c|}
\hline $\begin{array}{l}\text { includes a publicly accessible library, } \\
\text { educational establishment or museum and an } \\
\text { archive. }{ }^{108} \text { The permitted uses include making } \\
\text { the orphan work available to the public and } \\
\text { reproducing it for digitisation, indexing, } \\
\text { cataloguing, preservation or restoration. }{ }^{109} \text { The } \\
\text { orphan work must be used only to achieve aims } \\
\text { related to the institution's "public interest } \\
\text { mission": including the preservation of, the } \\
\text { restoration of, and the provision of cultural and } \\
\text { educational access to, works contained in its } \\
\text { collection. }{ }^{110} \text { The status of an orphan work } \\
\text { must first be established by the institution } \\
\text { following a complex process set out in the } \\
\text { CDPA (the cost of compliance with this process } \\
\text { is prohibitive for many CHIs). }{ }^{111} \text { Photographs } \\
\text { are not included in the orphan works provisions } \\
\text { in the CDPA - this is a significant flaw since } \\
\text { orphan photographs frequently comprise the } \\
\text { majority of items in a CHI's collection. }\end{array}$ & $\begin{array}{l}\text { in jurisdictions that already have orphan works } \\
\text { legislation in place will be able to make use of } \\
\text { New Zealand's orphan works. To be sure, the } \\
\text { Copyright Act includes a quasi-orphan works } \\
\text { provision (s 67) but this is of limited efficacy } \\
\text { since it also requires the user to make an } \\
\text { assumption that copyright has already expired } \\
\text { in the orphan work. The provision is } \\
\text { problematic in that there is no definition of a } \\
\text { "reasonable inquiry" or guidance as to when it } \\
\text { is "reasonable to assume". }{ }^{112} \\
\text { This article recommends that photographs are } \\
\text { included within any orphan works regime; that } \\
\text { a diligent search requirement is limited to } \\
\text { proposed commercial users of putative orphan } \\
\text { works, given the costs and complexities } \\
\text { associated with such a search; }{ }^{113} \text { and that CHIs } \\
\text { be permitted to display and digitise orphan } \\
\text { works for not-for-profit purposes, subject to a } \\
\text { legal requirement to remove a work from public } \\
\text { display should its copyright owner come } \\
\text { forward and subject to potential monetary } \\
\text { liability for a CHI being set at a minimum level. }\end{array}$ \\
\hline $\begin{array}{l}\text { The categories of works that may be copied by } \\
\text { librarians and archivists in the CDPA have been }\end{array}$ & $\begin{array}{l}\text { The Copyright Act provides more limited } \\
\text { copying options for archives. }{ }^{116} \text { Although this } \\
\text { provision does not include a specific }\end{array}$ \\
\hline
\end{tabular}

108 CDPA, sch ZA1, cl 2.

109 CDPA, sch ZA1, cl 1(2).

110 CDPA, sch ZA1, cl 1(4) and 6.

111 CDPA, sch ZA1, cls 1(4) and 3-6; and see Katie Childs Response to the Consultation on Copyright (National Museum Directors' Conference).

112 Copyright Act, s 67.

113 See, in relation to the diligent search requirement in Directive 2012/28/EU on certain permitted uses of orphan works OJ L299/5; and Simone Schroff, Marcella Favale, and Aura Bertoni "The Impossible Quest - Problems with Diligent Search for Orphan Works" (2017) 48 IIC 286.

116 Copyright Act, ss 55 and 56. 
expanded to include all published works. ${ }^{114}$ Importantly, each provision (apart from that pertaining to unpublished works) has been further amended to confirm that it cannot be overridden by contract. 115 The contract override is particularly significant for $\mathrm{CHIs}$ as many have items in their collections that have been acquired under individual contracts with the donor or vendor and are held subject to a plethora of different contractual terms.

Section 296ZE of the $\mathrm{CDPA}^{118}$ requires that a person wishing to exercise a permitted act using a TPM work (other than a computer program) must issue a "notice of complaint" to the Secretary of State if the TPM owner has not provided the ability to by-pass the TPM. ${ }^{119}$

The CDPA has been criticised for affording lesser protections to TPMs in software - there is no liability pertaining to circumventing a TPM in software. The legal ability to circumvent a TPM in software without going through a "complaints process" or approaching "a qualified person" (as the New Zealand Act requires) may be too broad as software underpins commercially valuable works, such as computer games. prohibition on contractual overrides for published works, it may be that the implication (by omission of any explicit provision in regard to published works) is that no contractual override is permitted. Similarly to the CDPA, the copying of unpublished works is explicitly subject to contractual override. ${ }^{117}$

Section 226D of the Copyright Act specifically allows a "qualified person", which includes an archivist, "to exercise a permitted act using a TPM circumvention device on behalf of the user of a TPM work". Moreover, "TPM work" in this provision includes all copyright works protected by a TPM, whereas the CDPA excludes computer programs from protections against circumvention measures.

114 CDPA, ss 41(1), 42(1) and 42A(1). Note that unpublished works may not be copied by librarians or archivists if the work has been published or communicated before it was deposited in the library or archive, or the copyright owner has not prohibited the copying of the work: CDPA, s 43(3).

115 CDPA, s 29(4B) and in relation to libraries and archives, see ss 41(5), 42(7) and 42A(6).

117 Copyright Act, s 56(2).

118 Implementing Directive 2001/29, above n 93, art 6(1).

119 For a timeline for the complaints process see GOV.UK "Guidance: Technological protection measures (TPMs) complaints process" (3 November 2014) <www.gov.uk>. 
As the above comparison table indicates, the CDPA amendments are helpful as a partial guide for recommended amendments to the Copyright Act but they do not provide a template. ${ }^{120}$ An additional important requirement for the Copyright Act is to support and protect the traditional culture of the Māori population, as New Zealand's indigenous people. Although much of traditional culture is not protected by copyright, and was likely never protected due to its age and communal authorship, nevertheless it cannot be described as having fallen into the public domain - a copyright concept. ${ }^{121}$

\section{THE PERMITTED EXCEPTIONS FOR CHIS AND MÄORI CULTURE}

It might well be argued that support and protection for the culture of indigenous peoples should be accepted without question as an ethical concept and should not require legal backing. In New Zealand, however, it is common to provide a constitutional rationale for supporting the rights of its indigenous people. Thus, one of the proposed objectives for the upcoming review of the Copyright Act is to "[e]nsure that the copyright system is consistent with the Crown's obligations under the Treaty of Waitangi." 122

Although the Treaty of Waitangi does not have the binding force of law in New Zealand, it is accepted to be a constitutional document and its principles are highly influential on the legal and policy environment. A report by the Waitangi Tribunal regarding the obligations imposed on the Crown by the Treaty in regard to Māori culture concluded that the Crown's obligations were confined to the Museum of New Zealand Te Papa Tongarewa, as it is the only New Zealand museum which is a Crown entity. ${ }^{123}$ The report states "as responsibility for regional museums (including the Auckland War Memorial Museum) sits with local authorities rather than the Crown, regional museums carry no Treaty obligations". ${ }^{124}$ This statement adds further support to this author's opinion that countries should not require legal backing to protect their indigenous people's culture, particularly as many of New Zealand's regional CHIs already acknowledge the need to protect traditional Māori culture, particularly from making digital images publicly available on the Internet. As explained in a report

120 See for example the well-argued proposal for a safe harbour regime in Samuel Coad "Digitisation, Copyright and the Glam Sector: Constructing a Fit-For-Purpose Safe Harbour Regime (2019) 50 VUWLR 1.

121 See discussion in Susan Corbett "Māori Cultural Heritage and Copyright Law: A Balancing Exercise" (2012) 6 NZIPJ 916 at 919.

122 Ministry of Business, Innovation and Employment Issues Paper: Review of the Copyright Act 1994 (November 2018) at [103].

123 Waitangi Tribunal Ko Aotearoa Tenei: A Report into the Claims Concerning New Zealand Law and Policy Affecting Māori Culture and Identity (Wai 262, 2011) vol 2 at 501

124 At 501 . 
for the New Zealand Law Foundation, ${ }^{125}$ "[i]n practice, regional museums which participated in the project have developed strict policies and protocols around their activities with items in their collection of Māori provenance."126

The insertion of a new provision pertaining to items of Māori provenance into the archive exceptions in the Copyright Act would provide legal support for the activities of New Zealand CHIs. Such a provision could, for example, require that prior to making a digital image of a Māori cultural item available online, CHIs must seek approval from a Māori advisory committee. ${ }^{127}$

\section{CONCLUSION}

The practices and processes of contemporary archives and other CHIs must be permitted to change in acknowledgement of both the availability of new technologies and also the changed expectations of society in regard to its cultural heritage. The privileging of state-funded CHIs by copyright law is no longer appropriate for modern culture. Permitted exceptions for CHIs should extend to any $\mathrm{CHI}$ whether it be a private or public enterprise; the limitations inherent within the permitted exceptions will provide sufficient protection for copyright owners. To provide certainty for CHIs, explicit prohibitions against contractual overrides should be included in the permitted exceptions. Clearly, the new provisions must also take into account the practical requirements of effective digital archiving, requiring multiple copying of a work with regular migration to new physical platforms. Moreover, the plethora of orphan copyright works held by CHIs should not be left unavailable to society until their term of protection expires. As explained in this article, the situation is more urgent in the case of born digital orphan works whose physical platforms are likely to become unusable well before their copyright expires. ${ }^{128}$ A failure to provide a practical and manageable process for New Zealand's orphan works risks the likelihood that businesses and CHIs in jurisdictions that already have orphan works legislation will be able to use orphan works of New Zealand provenance as the basis for new creative works. Many such works will qualify for their own copyright protection and, therefore, will be unavailable to New Zealand creators. Contemporary society rightly expects to have access to its "cultural heritage", the precise nature of which should be, at least to some extent, community driven rather than mandated by the state. Copyright law must assist CHIs to meet this expectation.

125 Corbett Archiving our Culture in a Digital Environment: Copyright law and Digitisation Practices in Cultural Heritage Institutions, above n 61.

126 See Corbett "Māori Cultural Heritage and Copyright Law: A Balancing Exercise", above n 121, at 916-917.

127 For the balance that should be considered by the committee between the rights of the community in regard to culture, as supported by cultural property theory, and the rights of Māori to control the uses to which their culture may be put see Corbett "Māori Cultural Heritage and Copyright Law: A Balancing Exercise", above n 121 , at 917 .

128 See United Nations Educational Scientific and Cultural Organization UNESCO Charter on the Preservation of the Digital Heritage, above n 19; and United Nations Educational Scientific and Cultural Organization "Memory of the World", above n 19. 
